Western University

Scholarship@Western

2012

\title{
Vestibular stimulation enhances hippocampal long- term potentiation via activation of cholinergic septohippocampal cells
}

Leung L. Stan

University of Western Ontario, sleung@uwo.ca

Follow this and additional works at: https://ir.lib.uwo.ca/physpharmpub

Part of the Medical Physiology Commons, and the Pharmacy and Pharmaceutical Sciences Commons

Citation of this paper:

L. Stan, Leung, "Vestibular stimulation enhances hippocampal long-term potentiation via activation of cholinergic septohippocampal cells" (2012). Physiology and Pharmacology Publications. 70.

https://ir.lib.uwo.ca/physpharmpub/70 
Provided for non-commercial research and education use. Not for reproduction, distribution or commercial use.

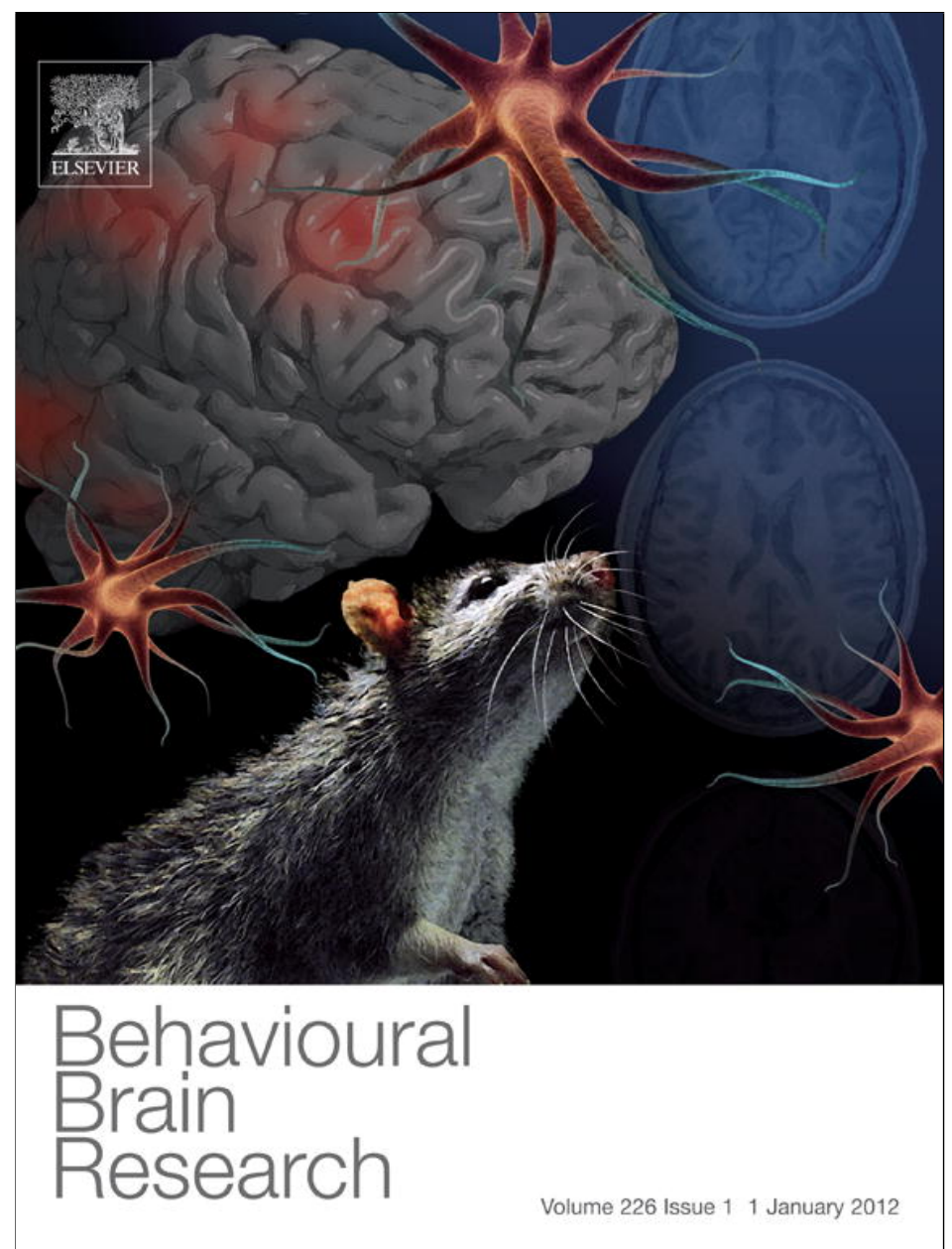

(This is a sample cover image for this issue. The actual cover is not yet available at this time.)

This article appeared in a journal published by Elsevier. The attached copy is furnished to the author for internal non-commercial research and education use, including for instruction at the authors institution and sharing with colleagues.

Other uses, including reproduction and distribution, or selling or licensing copies, or posting to personal, institutional or third party websites are prohibited.

In most cases authors are permitted to post their version of the article (e.g. in Word or Tex form) to their personal website or institutional repository. Authors requiring further information regarding Elsevier's archiving and manuscript policies are encouraged to visit:

http://www.elsevier.com/copyright 
Research report

\title{
Vestibular stimulation enhances hippocampal long-term potentiation via activation of cholinergic septohippocampal cells
}

\author{
Siew Kian Tai ${ }^{a}$, L. Stan Leung ${ }^{a, b, *}$ \\ a Graduate Program in Neuroscience, University of Western Ontario, London, N6A 5C1, Canada \\ ${ }^{\mathrm{b}}$ Department of Physiology and Pharmacology, University of Western Ontario, London, N6A 5C1, Canada
}

\section{A R T I C L E I N F O}

\section{Article history:}

Received 29 October 2011

Received in revised form 29 March 2012

Accepted 8 April 2012

Available online $\mathrm{xxx}$

\section{Keywords:}

Long-term potentiation

Acetylcholine

Medial septum

192 IgG-saporin

Atropine sulfate

Rotation

\begin{abstract}
A B S T R A C T
Vestibular stimulation induced acetylcholine release in the hippocampus, and acetylcholine is known to facilitate long-term potentiation (LTP) in the hippocampus. Thus, we hypothesize that vestibular stimulation enhances LTP in CA1 in freely behaving rats, and this enhancement depends on the activation of septohippocampal cholinergic neurons. Field excitatory postsynaptic potentials were recorded in CA1 area of behaving rats following stimulation of the basal dendritic afferents. LTP was induced by a single stimulation train $(100$ pulses at $200 \mathrm{~Hz})$ during passive whole-body rotation or during awakeimmobility. LTP induced during rotation was significantly larger than that induced during immobility. Pretreatment with cholinergic antagonist atropine sulfate $(50 \mathrm{mg} / \mathrm{kg}$ i.p.) abolished the facilitation of LTP during rotation as compared to immobility. Selective lesion of cholinergic cells in the medial septum (MS) with $192 \mathrm{IgG}$-saporin $(0.49 \mu \mathrm{g}$ in $1.4 \mu \mathrm{l})$ also abolished the difference in LTP induced during rotation and immobility, which was found in sham-lesion rats. 192 IgG-saporin lesioned rats, as compared to sham-lesion rats, revealed a depletion of MS cells immunopositive to choline acetyltransferase and paling of acetylcholinesterase staining in the hippocampus, without significant change in the number of parvalbumin-immunopositive cells. We conclude that enhancement of LTP during vestibular stimulation is mediated by the activation of cholinergic septohippocampal cells. This is the first direct evidence that vestibular stimulation facilitates hippocampal synaptic plasticity via a cholinergic input.
\end{abstract}

(C) 2012 Elsevier B.V. All rights reserved.

\section{Introduction}

Acetylcholine modulates a wide array of cognitive functions, including arousal, attention, learning and memory [1-3]. Cholinergic input to the hippocampus originating predominantly from the medial septum (MS) is particularly important for learning and memory [4-7]. Selective ablation of septal cholinergic neurons by intraseptal microinjection of the immunotoxin 192 immunoglobulin G-saporin (192 IgG-saporin) caused spatial learning and memory impairments in some [8-10] but not all experiments [11-13]. The cholinergic hypothesis of Alzheimer's disease postulates that degeneration of cholinergic neurons in the basal forebrain including the MS contributes to the cognitive deficits of Alzheimer's disease [14,15].

Long-term potentiation (LTP), a long-lasting increase in synaptic transmission, is widely regarded as the cellular correlate of learning and memory [16-18]. LTP was first described in the hippocampus of anesthetized and behaving animals $[19,20]$, and there has

\footnotetext{
* Corresponding author at: Department of Physiology and Pharmacology, University of Western Ontario, Medical Sciences Building, Rm 236, London, Ontario, N6A 5C1, Canada. Tel.: +1 519850 2400; fax: +1 5196613827.

E-mail address: sleung@uwo.ca (L.S. Leung).
}

been much evidence that acetylcholine modulates hippocampal LTP. Application of the cholinergic agonists enhanced hippocampal LTP in vitro [21-23]. In anesthetized rats, hippocampal LTP was facilitated by tetanic stimulation of the MS, and this facilitation was blocked by systemic administration of cholinergic antagonists $[24,25]$. In behaving rats, our laboratory reported that LTP of the basal dendritic synapses on hippocampal CA1 pyramidal cells was enhanced when induced during walking as compared to that induced during immobility [26]. It was inferred that the endogenous release of acetylcholine, which was higher during walking than immobility [27], facilitated basal dendritic LTP during walking as compared to immobility. Systemic blockade of cholinergic receptors by scopolamine or lesion of septohippocampal cholinergic neurons by 192 IgG-saporin abolished the facilitation of basal dendritic LTP during walking as compared to immobility [26].

The relation of LTP facilitation and hippocampal theta rhythm in behaving rats is indirect. After systemic cholinergic blockade, LTP facilitation was abolished [26] but theta rhythm remained correlated with voluntary movements $[28,29]$. Theta power during walking was reduced [30-32] or not significantly changed [33] after 192 IgG-saporin lesion of cholinergic septal neurons. These results suggest the existence of a non-cholinergic, atropine-resistant theta during voluntary movements. Recently, we showed that vestibular stimulation by passive rotation generated a continuous theta 
A

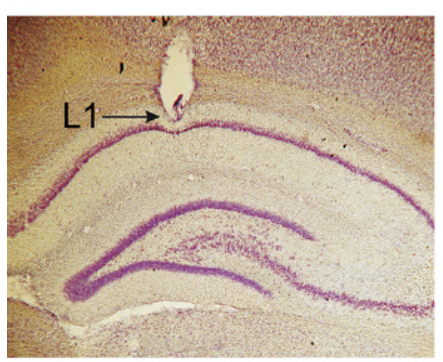

D

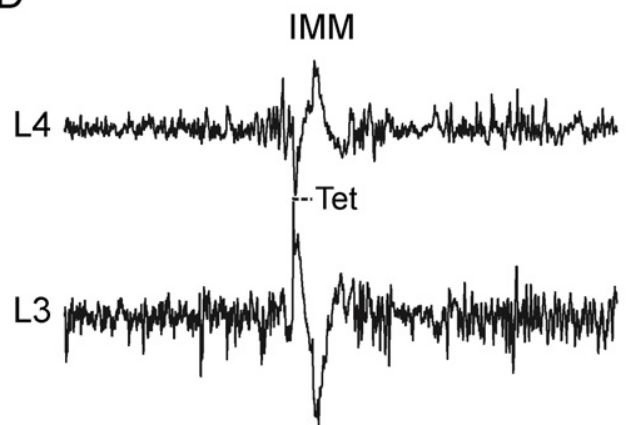

B

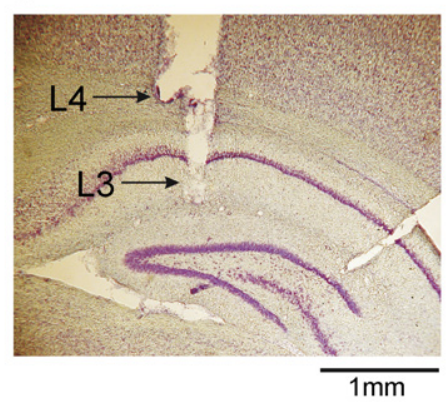

C<smiles>[CH]C(C)CCC</smiles><smiles>CC(C)CCCC(C)C</smiles>

E<smiles>[Mg][SeH]</smiles>

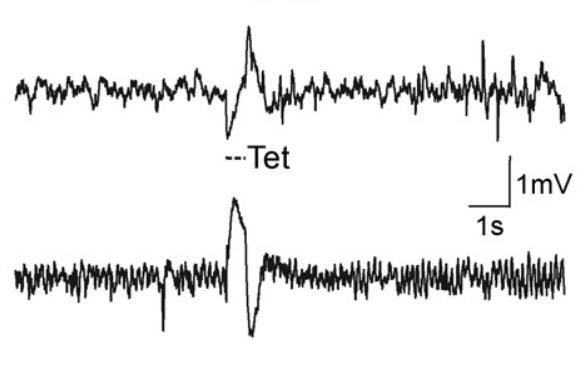

Fig. 1. Recording of hippocampal basal-dendritic evoked potential and EEG using implanted electrodes in CA1. (A, B) Representative coronal sections showing locations of (A) the anterior stratum oriens stimulating electrode L1 at P3.2, L1.7, (B) the posterior surface alvear L4 and deep L3 stratum radiatum recording electrode pair at P4.6, L2.8. (C) Representative basal-dendritic average fEPSP at L3 and L4 following cathodal stimulation of L1; stimulus artifacts are indicated by filled circles. (D, E) EEG from L3 and L4 were recorded around the time of tetanus (Tet; dotted line) during awake-immobility (IMM; D) and rotation (SPIN; E). Note the presence of a theta rhythm during rotation and large-amplitude irregular activity during immobility.

rhythm of about $6 \mathrm{~Hz}$ in immobile rats, and this theta rhythm was atropine-sensitive and required the integrity of septohippocampal cholinergic innervation [33]. The increase in acetylcholine level in the hippocampus following caloric vestibular stimulation [34,35] was inferred to induce an atropine-sensitive theta rhythm during passive rotation [33]. Under urethane anesthesia, the dominant hippocampal theta rhythm is atropine-sensitive and its frequency or presence correlated with acetylcholine release [36,37].

Based on the presence of an atropine-sensitive theta rhythm during passive rotation in behaving rats, we hypothesize that basal dendritic LTP in CA1 induced during passive rotation (SPIN) is larger than that induced during awake-immobility without rotation (IMM). We also hypothesize that the facilitation of LTP induced during SPIN as compared to IMM is mediated by the activity of cholinergic septohippocampal cells.

\section{Materials and methods}

\subsection{Lesion and control rats}

Experiments were conducted on 21 adult male Long Evans hooded rats (244-320 g; Charles River Canada, Quebec, Canada). All animals were given food and water ad libitum and housed in pairs in Plexiglas cages under climate-controlled conditions on a $12 \mathrm{~h} \mathrm{light/dark} \mathrm{cycle} \mathrm{(lights} \mathrm{on} \mathrm{at} \mathrm{7:00} \mathrm{a.m.).} \mathrm{Five} \mathrm{different} \mathrm{exper-}$ iments were done: intact rats with no lesions were used in (1) the first (IMM vs. SPIN) and (2) second (atropine-SPIN vs. saline-SPIN), and (3) third experiment (atropine-IMM vs. saline-IMM). Rats with cholinergic neurons in the MS lesioned by $192 \mathrm{IgG}$-saporin (192 IgG-SAP) were used in (4) the fourth experiment (IMM vs. SPIN), and sham-lesion rats with saline infused in the MS were used in (5) the fifth experiment (IMM vs. SPIN). All experimental procedures were approved by the local Animal Use Committee and conducted according to the guidelines of Canadian Council for Animal Care. All efforts were taken to minimize the pain and suffering of animals.

\subsection{Electrode implantation}

Under sodium pentobarbital ( $60 \mathrm{mg} / \mathrm{kg}$ i.p.) anesthesia, bipolar electrodes were placed bilaterally in the dorsal hippocampus $(\mathrm{P}+4.6 \mathrm{~mm}, \mathrm{~L} \pm 2.8 \mathrm{~mm} ; \mathrm{P}+3.2 \mathrm{~mm}, \mathrm{~L}$ $\pm 1.7 \mathrm{~mm}$ ) as described previously [26,38]. Coordinates were adapted from the atlas of Paxinos and Watson [39]. Each electrode comprised of a $125 \mu \mathrm{m}$ stainless steel wire insulated with Teflon, except at the cut tip and were used for either recording or stimulation. Recording electrodes were implanted to straddle the cell layer of CA1, with the deep electrode in the stratum radiatum and the surface electrode in the alveus or stratum oriens (referred to as the stratum oriens electrode). Stimulating electrodes were placed in the stratum oriens on the same side anterior to the recording electrodes, or homotopically on the opposite side. Screws in the skull (one over the frontal cortex and one over the cerebellum) served as the stimulus anode and the recording ground respectively. The depths of stimulating and recording electrodes were optimized by monitoring evoked potentials during surgery. All electrodes and screws were fixed on to the skull with dental cement. Hippocampal EEGs and evoked potentials were recorded at least one week after electrode implantation.

\subsection{Lesion of cholinergic cells in the medial septum}

Cholinergic neurons in the MS were lesioned using 192 IgG-saporin (Advanced Targeting Systems, San Diego, CA) under sodium pentobarbital ( $60 \mathrm{mg} / \mathrm{kg}$ i.p.) anesthesia. It consists of a p75 receptor antibody $192 \operatorname{IgG}$ which is conjugated to saporin, a ribosome-inactivating toxin. Given that cholinergic neurons are the only cells in the MS region that express p75 receptor, 192 IgG-saporin destroys cholinergic neurons without affecting non-cholinergic cells [40,41]. 192 IgG-saporin was diluted with sterile saline, loaded into a Hamilton syringe, and infused bilaterally into the MS $(A+0.5, L \pm 0.5)$. At each lateral track, the 30 -gauge cannula was first lowered to V 5.7, and then to V 7.8. 192 IgG-saporin $(0.35 \mu \mathrm{g} / \mu \mathrm{l} ; 0.3 \mu \mathrm{l}$ at V 5.7, $0.4 \mu \mathrm{l}$ at V 7.8) was infused at a constant rate of $0.5 \mu \mathrm{l} / 10$ minutes using an infusion pump (Harvard Apparatus, South Natick, MA). After each infusion, the needle remained in place for $10 \mathrm{~min}$. Sham lesion rats were infused with equal volumes of saline. $192 \mathrm{IgG}$-saporin and saline-infused rats were implanted with depth electrodes immediately or 1-2 days after MS infusion. Hippocampal EEGs and evoked potentials were recorded 2-4 weeks following lesion.

\subsection{Recording and analysis of evoked potentials and EEC}

Animals were habituated to the recording environment for at least 2 days, prior to the start of experiments. Recording was carried out between 10:00a.m. and 7:00 p.m. Photoisolated current stimulus pulses $(0.2 \mathrm{~ms})$ were delivered cathodally to one stimulating electrode and monopolar recordings were made. A stimulating electrode, ipsi- or contra-lateral to a recording pair of CA1 electrodes, evoked a basal-dendritic field excitatory postsynaptic potential (fEPSP) when a negative field potential was evoked at the surface (stratum oriens) electrode and a positive potential was evoked at the deep (stratum radiatum) electrode. Two channels of evoked responses were filtered at $0.1 \mathrm{~Hz}$ to $3 \mathrm{kHz}$ and sampled at $10 \mathrm{kHz}$, and 
averaged evoked potentials (AEPs) of eight sweeps were acquired online by a custom microcomputer program.

AEPs were recorded during awake-immobility before and after LTP induction. Baseline AEPs were recorded for 1-2 h. LTP was induced by a high-frequency stimulus train (tetanus) delivered either during awake-immobility or passive rotation described below. The train consisted of 100 pulses at $200 \mathrm{~Hz}$ ( $5 \mathrm{~ms}$ interpulse interval) at a stimulus intensity of 1-1.5 × fEPSP threshold. fEPSP threshold is the lowes stimulus intensity at which an evoked response can be visually detected. Generally, tetanus did not evoke an afterdischarge. However, a few experiments in which a short $(<15 \mathrm{~s})$ afterdischarge was evoked were included, since the magnitude of LTP (expressed at a ratio of the baseline) was similar to experiments without afterdischarge [42]. Following tetanus, AEPs were recorded at "fixed" times at 5, 10, 15, 20, $30,60,90,120,150$ and $180 \mathrm{~min}$. Previous data showed that LTP magnitude was not significantly different among test pulses of $1.5-2 \times$ fEPSP threshold intensity [43]; therefore, all AEPs were recorded with test pulse of $1.5 \times$ the fEPSP threshold. Input-output curves were obtained from fEPSP responses of five different stimulus intensities $(1,1.2,1.5,2$ and 4 times fEPSP threshold) recorded during baseline, at $1 \mathrm{~h}$ and $2 \mathrm{~h}$ after tetanus. The maximal slope of the fEPSP during the falling or rising phase (within $2 \mathrm{~ms}$ interval) was measured from the AEPs. The baseline value was obtained by averaging the last six AEPs (over 30-60 min period) before tetanus. For each experiment, the response after tetanus was normalized by the baseline average.

EEG was sampled at $200 \mathrm{~Hz}$ after averaging five consecutive samples digitized at $1 \mathrm{kHz}$, which contributed $3 \mathrm{~dB}$ and $10 \mathrm{~dB}$ attenuation points at $84 \mathrm{~Hz}$ and $180 \mathrm{~Hz}$, respectively. Artifact-free segments of the EEG were manually selected, with each segment consisting of 1024 points or $5.12 \mathrm{~s}$ duration. A power spectrum was constructed from at least one segment, after smoothing and averaging, spectral estimates had $0.195 \mathrm{~Hz}$ resolution, $2.15 \mathrm{~Hz}$ bandwidth (interval of smoothing) and $>60$ of freedom [29].

\subsection{Experimental design}

In the first experiment, intact rats were given tetanus during awake-immobility or rotation. During awake-immobility (IMM), the motionless rat was in an aler state with eyes opened and head held against gravity. For rotation (SPIN), the rat was placed in a small container $(26 \times 23 \times 21 \mathrm{~cm})$ and electrodes connected through a slide-wire commutator. A steel rod connected to the base of the container was inserted into the shaft of a drill that was adjusted to rotate at $36-49 \mathrm{rpm}$ in a vertical axis. In our previous study, when the rat was rotated at various speeds - low (20-35 rpm), medium (36-49 rpm) and high (50-70 rpm), a stable hippocampa theta rhythm was observed during periods of immobility (up to $5 \mathrm{~min}$ ) in which the rat "braced" itself by extending its forelimbs, flexing its hind limbs and tilting its head, and then remained in the same posture without head and limb movements [33]. In this study, only medium speed (36-49 rpm) was used because it produced more consistent and longer periods of immobility as compared to low speed. LTP was induced during immobility or rotation (within a period of immobility). In addition, tetanus was generally given $2-3$ min after the start of rotation.

In the second experiment, intact rats were injected with cholinergic receptor antagonist atropine sulfate $(50 \mathrm{mg} / \mathrm{kg}$, i.p.) or an equal volume of saline $15 \mathrm{~min}$ before tetanus was given during rotation (within a period of immobility). In the third experiment, intact rats were injected with atropine sulfate $(50 \mathrm{mg} / \mathrm{kg}$, i.p.) or saline 15 min before tetanus was given during immobility. Although atropine sulfate is often described as a muscarinic receptor antagonist [44,45], it has been shown to interact with neuronal nicotinic receptors $[46,47]$. Therefore, atropine sulfate is regarded as a non-selective cholinergic receptor antagonist in this study.

In the fourth experiment, rats infused with 192 IgG-saporin (192 IgG-SAP) were given tetanus during immobility or rotation (within a period of immobility). In the fifth experiment, rats infused with saline into the MS (Sham) were given tetanus during immobility or rotation (within a period of immobility).

In all experiments, LTP tests were conducted in a random order using the same tetanic stimulus parameters. Tetanus was given up to 5 times in each rat, separated by at least 5 days. No LTP could be demonstrated 5 days after a tetanus.

\subsection{Histology}

At the end of experiments, rats were deeply anesthetized with $30 \%$ urethane and perfused through the heart with $400 \mathrm{ml}$ of cold saline followed by $500 \mathrm{ml}$ of cold $4 \%$ paraformaldehyde solution in $0.1 \mathrm{M}$ phosphate buffer (PB; $\mathrm{pH} 7.4)$. The brain was removed and post-fixed in the latter solution at $4{ }^{\circ} \mathrm{C}$. Acetylcholinesterase (AChE) staining was performed on hippocampal sections. Choline acetyltransferase (ChAT) and parvalbumin (Parv) immunohistochemistry were carried out on MS sections. Using a freezing microtome, the hippocampus was sectioned at $40 \mu \mathrm{m}$ within $12 \mathrm{~h}$ of fixing while the rest of the brain was kept in $18 \%$ sucrose in phosphate-buffered saline for at least $72 \mathrm{~h}$ at $4{ }^{\circ} \mathrm{C}$. For the AChE staining, hippocampal sections were mounted on chrome-alum gelatin coated slides. AChE staining protocol was modified from the Koelle copper thiocholine method [48], using acetylthiocholine iodide as a false substrate to tag the AChE enzyme and ethopropazine as an inhibitor of non-specific cholinesterases.

For the ChAT and Parv staining, the MS was sectioned at $40 \mu \mathrm{m}$ and they were first incubated in $1 \%$ sodium borohydride in $0.1 \mathrm{M}$ PB for $15 \mathrm{~min}$ and subsequently
A
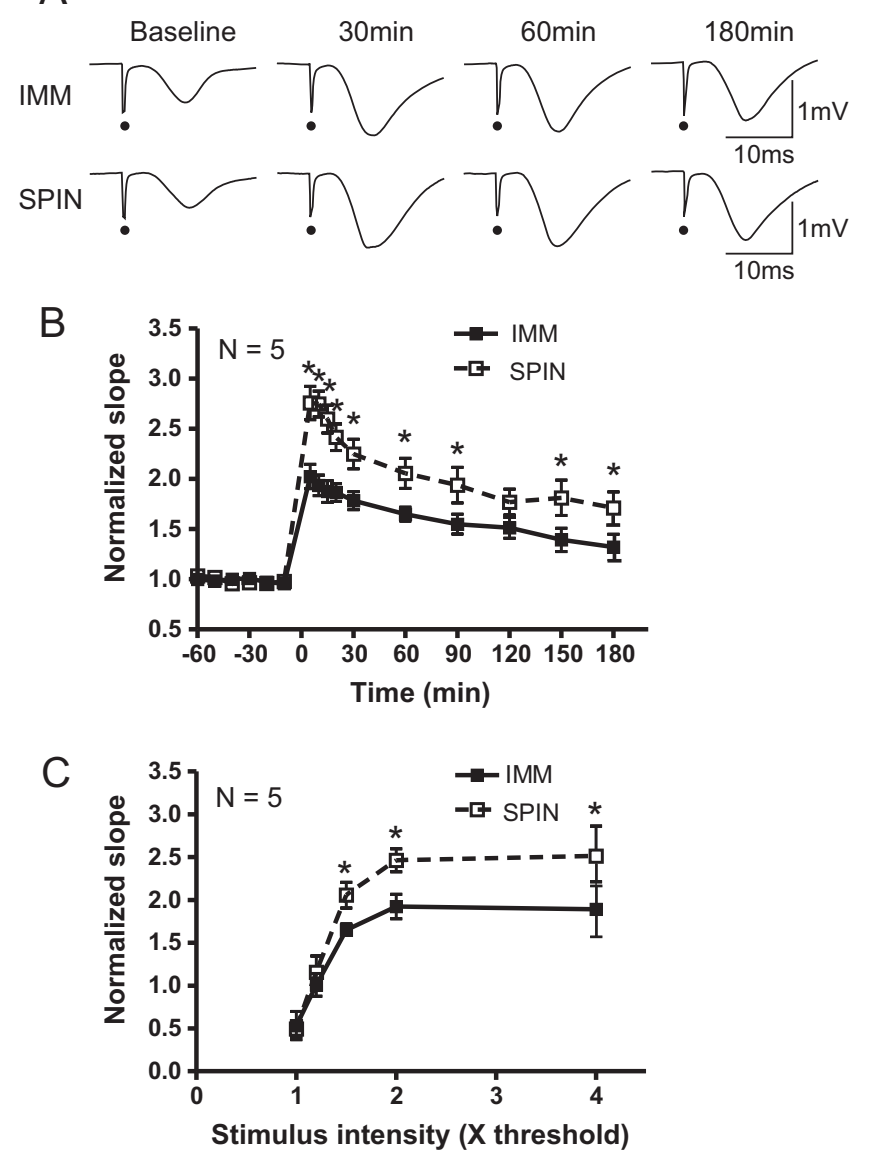

Fig. 2. Basal-dendritic LTP was larger when induced during rotation (SPIN) than when induced during immobility (IMM) in intact rats. (A) Traces of fEPSP at the stratum oriens electrode of a representative rat at baseline (before tetanus), 30, 60 and $180 \mathrm{~min}$ after tetanus. To facilitate comparison, the fEPSPs were scaled to make the peak amplitudes of the baseline response appear identical. (B) Normalized fEPSP slope (mean \pm SEM) was plotted as a function of time. The maximal falling slope of the fEPSP (within $2 \mathrm{~ms}$ interval) after tetanus was normalized by the grand average of the last six average fEPSPs taken prior to tetanus. LTP was larger when tetanus was delivered during SPIN than during IMM, as confirmed by a significant repeated measures block two-way (group $\times$ behavior) ANOVA. (C) Normalized fEPSP slope was plotted as a function of stimulus intensity $(x$ threshold $) 1 \mathrm{~h}$ after LTP induction during IMM or SPIN. ${ }^{*} P<0.01$ : difference between IMM and SPIN using Newman-Keuls test following a significant repeated measures block two-way ANOVA.

rinsed in PB. To block non-specific labeling, they were incubated in $10 \%$ normal goat serum (Sigma-Aldrich, St. Louis, MO) in $0.1 \mathrm{M}$ PB containing $0.1 \%$ Triton X-100 (Sigma-Aldrich) for $1 \mathrm{~h}$ at room temperature. The sections were rinsed briefly in $\mathrm{PB}$ and incubated at $4{ }^{\circ} \mathrm{C}$ for $48 \mathrm{~h}$ in primary antibody solution containing mouse monoclonal ChAT (1:200; Cedarlane, Burlington, Ontario, Canada) or Parv (1:100 Sigma-Aldrich) in $1 \%$ normal goat serum. Sections were rinsed in three changes of $\mathrm{PB}$ and followed by incubation in biotin-conjugated goat anti-mouse secondary antiserum (1:200; Jackson ImmunoResearch, West Grove, PA) for $1 \mathrm{~h}$ in room temperature. The sections were then rinsed several times in PB. ABC complex solution (Vector Laboratories, Burlington, Ontario, Canada) was prepared $20 \mathrm{~min}$ before use by adding equal volumes of solutions $A$ and $B$ in $\mathrm{PB}(1: 1: 100)$. The sections were incubated in the $A B C$ complex solution for $1 \mathrm{~h}$ at room temperature. Following three washes in $\mathrm{PB}$, the sections were incubated in a solution containing $0.05 \%$ diaminobenzidine tetrahydrochloride (DAB, Sigma-Aldrich) and $0.03 \%$ hydrogen peroxide in $\mathrm{PB}$ at room temperature in a fume hood until they reached the desired color intensity (1-3 min). The sections were then rinsed several times in PB, mounted on glass slides. Finally, they were dehydrated in a series of $70 \%, 95 \%$ and $100 \%$ ethyl alcohol, cleared in xylene $(5 \mathrm{~min} \times 2)$ and cover-slipped with DePex (BDH, VWR International Mississauga, Ontario, Canada) mounting medium.

The number of ChAT- and Parv-positive cells was quantified in three representative coronal sections $(40 \mu \mathrm{m})$ at anterior $(\sim \mathrm{A} 0.7)$, middle $(\sim \mathrm{A} 0.4)$ and posterior $(\sim \mathrm{A}$ 0.2 ) levels of the medial septum-diagonal band of Broca region. Images of selected sections were captured with a digital camera using $\times 100$ magnification in a microscope, and cells were counted from the digital images by another person who was 
A

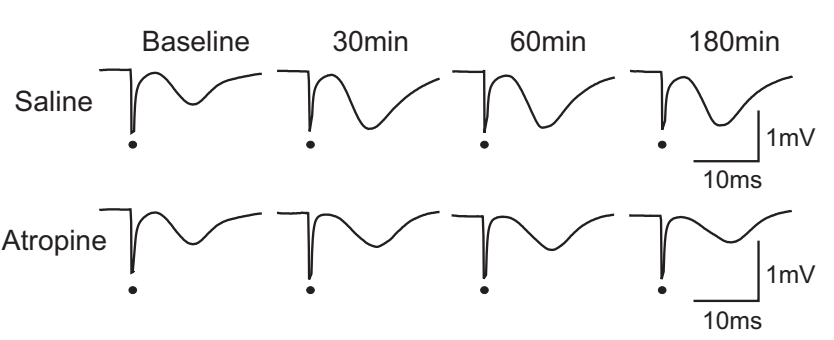

C

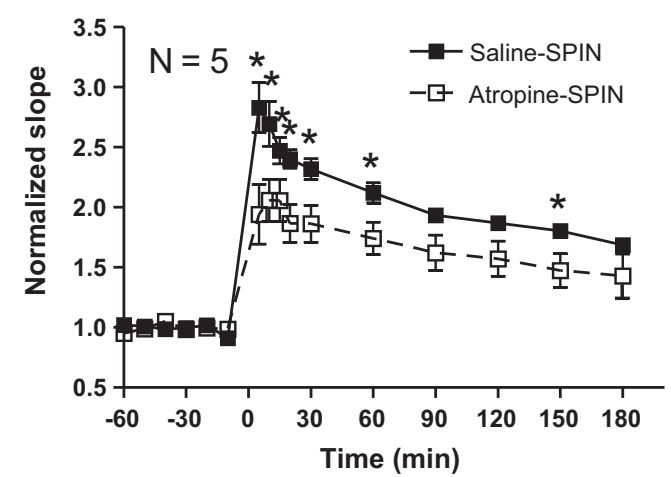

B

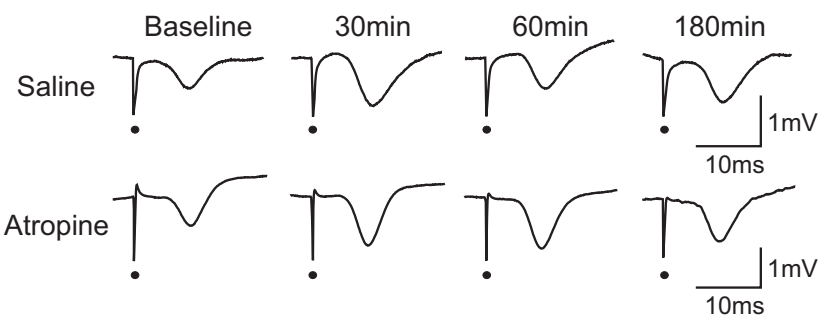

D

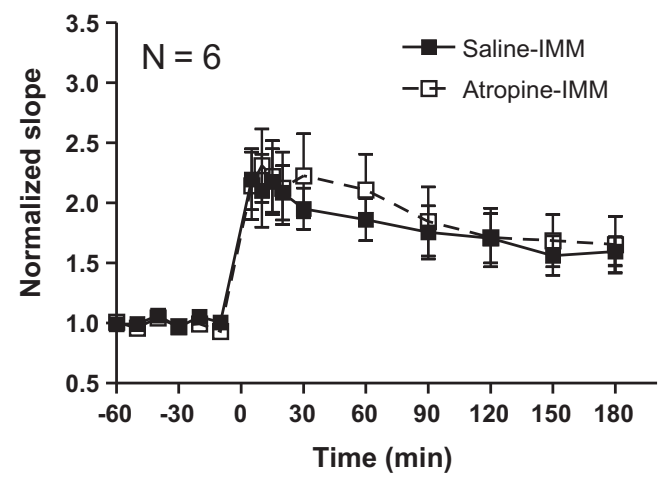

Fig. 3. Rotation-associated enhancement of LTP was suppressed by cholinergic antagonist atropine sulfate ( $50 \mathrm{mg} / \mathrm{kg}$, i.p.). Traces of fEPSP at the stratum oriens electrode of representative rats at baseline (before tetanus), 30, 60 and 180 min after tetanus, with tetanus given during rotation (SPIN; A) and immobility (IMM; B) 15 min after administration of atropine sulfate or saline. The fEPSPs were scaled to make peak amplitudes of the baseline responses appear identical. Normalized fEPSP slopes (mean \pm SEM) with LTP induced during SPIN (C) and IMM (D) after injection of either atropine sulfate or saline. Repeated measures block two-way ANOVA revealed a significant treatment effect in the SPIN group, but not in the IMM group. ${ }^{*} P<0.05$ : difference between saline and atropine sulfate using Newman-Keuls test following a significant repeated measures block two-way ANOVA.

unaware of the treatment history. Electrode placements were histologically verified in $40 \mu \mathrm{m}$ thionin-stained brain sections.

\subsection{Statistical analysis}

One- or two-way ANOVAs were carried out, followed by Newman-Keuls post hoc if the main or interaction effect was statistically significant $(P<0.05)$. All statistical analyses were performed using Prism 4.0 (GraphPad Software Inc., La Jolla, CA) and GB Stat (Dynamic Microsystems Inc., Silver Spring, MD).

\section{Results}

Ipsilateral or contralateral stimulation of stratum oriens in CA1 (Fig. 1A) evoked a typical basal dendritic fEPSP which was negative at the alveus or stratum oriens electrode and positive at the deep electrode in the stratum radiatum (Fig. 1B and C). The hippocampal EEG displayed large-amplitude irregular activity during immobility (IMM; Fig. 1D) and a theta rhythm during rotation (SPIN; Fig. 1E). FFT analysis of hippocampal EEG during rotation but prior to tetanus showed an average theta peak frequency of $6.14 \pm 0.33 \mathrm{~Hz}$ at the stratum oriens electrode and $6.19 \pm 0.33 \mathrm{~Hz}$ at the stratum radiatum electrode ( $n=5$ rats). The average stimulus intensity for a single-pulse ( $0.2 \mathrm{~ms}$ duration) threshold fEPSP response $(22 \pm 1 \mu \mathrm{A}$, $n=21$ rats $)$ or for tetanic stimulation $(26 \pm 2 \mu \mathrm{A}, n=52$ sessions $)$ was not significantly different across experimental groups (oneway ANOVA, $P>0.1$ ). In each rat, AEPs elicited prior to tetanus by the same stimulus intensity were analyzed. The average slope $(n=16$ sessions) had decayed to $82.0 \pm 3.3 \%$ at the stratum oriens electrode and $85.0 \pm 3.5 \%$ at the stratum radiatum electrode, compared to the previous session.

After a $0.5-\mathrm{s} 200-\mathrm{Hz}$ train stimulation of stratum oriens, enhancement of basal dendritic fEPSPs was found at both stratum oriens and stratum radiatum recording electrodes. The figures will present only the negative fEPSPs recorded at the alveus/stratum oriens electrode, which was directly generated by a basal dendritic excitatory sink in CA1 [49].

\subsection{Induction of basal-dendritic LTP in normal intact rats}

LTP was shown as an increase in the slope and peak of the fEPSPs, above that during baseline. The LTP induced during IMM peaked at about 2 times the average baseline slope immediately after tetanus, and then gradually declined to about 1.5 times baseline slope at 180 min after tetanus (Fig. 2A and B). LTP induced during passive rotation (SPIN) showed a magnitude larger than that induced during IMM, but with a similar time course (Fig. 2A and B). Repeated measures block two-way ANOVA revealed significant group (SPIN vs IMM) and interaction effects for the potentiation recorded at the stratum oriens electrode (group effect, $F_{(1,4)}=22.93, P<0.009$; group $\times$ time, $\left.F_{(9,36)}=35.40, P<0.0001\right)$. Newman-Keuls post hoc tests showed a significant difference between SPIN and IMM at all time points except 120 min post-tetanus $(P<0.01)$. In addition, there was a significant difference in the LTP at the stratum radiatum electrode (group: $F_{(1,4)}=17.18, P<0.02$; group $\times$ time: $F_{(9,36)}=9.57$, $P<0.0001$; repeated measures block two-way ANOVA). For stratum radiatum electrode, Newman-Keuls post hoc tests revealed significance at $5-15$ min post-tetanus $(P<0.01)$.

Input-output curves of the fEPSP slopes at the stratum oriens electrodes, recorded at $1 \mathrm{~h}$ after tetanus, also confirmed that LTP was larger when induced during SPIN as compared that induced during IMM, at different stimulus intensities (Fig. 2C). Repeated measures block two-way ANOVA showed significant group and interaction effects between SPIN and IMM for the potentiation recorded $1 \mathrm{~h}$ post-tetanus (group: $F_{(1,4)}=15.51, P<0.02$; group $\times$ stimulus intensity: $\left.F_{(4,16)}=7.11, P<0.002\right)$. Newman-Keuls 
A

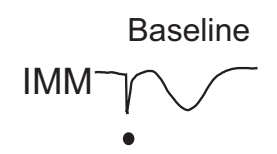

Sham

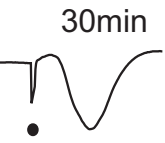

$7^{60 \mathrm{~min}}$

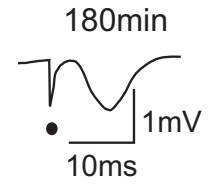

SPIN]
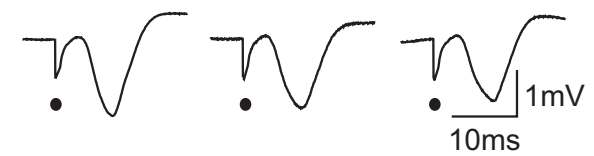

Sham

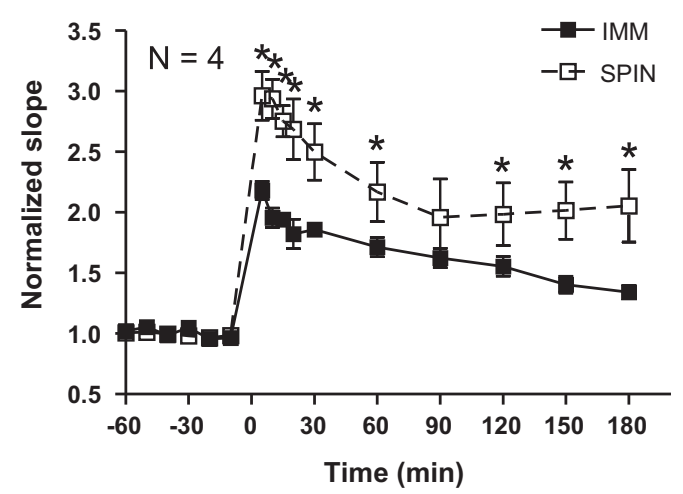

B 192 lgG-SAP
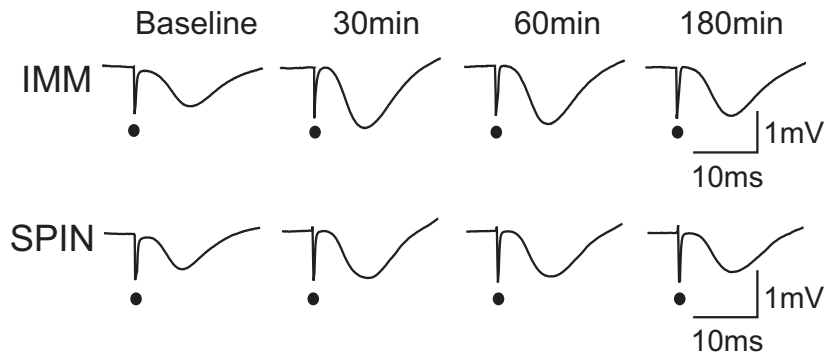

D

192 lgG-SAP

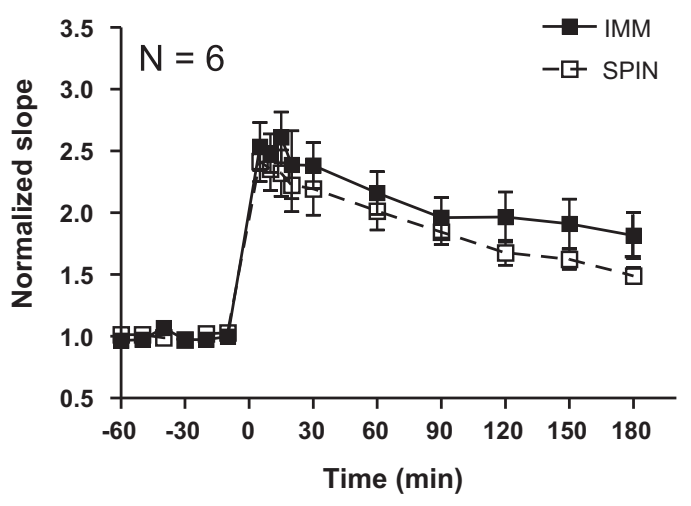

Fig. 4. Cholinergic lesion of the medial septum (MS) abolished the difference in hippocampal basal-dendritic LTP induced during immobility (IMM) and rotation (SPIN). (A, B) Traces of fEPSP at the stratum oriens electrode of representative rats at baseline (before tetanus), 30, 60 and 180 min after tetanus in sham-lesion (A) and 192 IgG-saporin (192 IgG-SAP) lesion rats (B). The fEPSPs were scaled to make peak amplitudes of the baseline responses appear identical in A and B. (C, D) Normalized fEPSPs slopes (mean \pm SEM) were larger when tetanus was induced during SPIN compared to during IMM in sham-lesion rats (C). However, this behavioral modulation of LTP was absent in 192 IgG-SAP lesion rats (D). Repeated measures block two-way ANOVA revealed a significant IMM versus SPIN effect in sham-lesion rats but not in the 192 IgG-SAP lesion rats. ${ }^{*} P<0.05$ : difference between IMM and SPIN using Newman-Keuls test following a significant repeated measures block two-way ANOVA.

post hoc tests revealed that a significant difference between SPIN and IMM at stimulus intensities $1.5-4 \times$ fEPSP threshold $(P<0.01)$.

\subsection{Effect of cholinergic blockade on LTP during rotation}

Since caloric stimulation of the vestibular receptors increased hippocampal acetylcholine levels [34,35] and recent evidence suggests that theta rhythm during passive rotation is atropinesensitive [33,50,51], the increased cholinergic activity during rotation may be responsible for the facilitation of LTP. Therefore, to elucidate the involvement of cholinergic receptors in LTP during rotation, rats were injected with atropine sulfate $(50 \mathrm{mg} / \mathrm{kg}$, i.p.) or an equal volume of saline $15 \mathrm{~min}$ before the delivery of tetanus during SPIN (Fig. 3A and C). At the stratum oriens electrode, the average LTP induced during SPIN following atropine sulfate injection was smaller than that induced following saline injection (Fig. 3A and C). Repeated measures block two-way ANOVA revealed a non-significant main effect $\left(F_{(1,4)}=6.68, P=0.061\right)$, but a significant interaction effect $\left(F_{(9,36)}=31.85, P<0.0001\right)$. Newman-Keuls post hoc tests showed that LTP, when tetanized during SPIN, was significantly smaller after atropine sulfate than after saline at times 5-60 min and 150 min after tetanus $(P<0.05)$. Similarly, when measured at the stratum radiatum electrode, LTP induced during SPIN following atropine sulfate was smaller than that following saline as shown by a non-significant main effect $\left(F_{(1,4)}=5.53, P=0.078\right)$ and a significant interaction effect $\left(F_{(9,36)}=30.76, P<0.0001\right.$; repeated measures block two-way ANOVA). Newman-Keuls post hoc tests revealed significance at $5-15$ min post-tetanus (at least $P<0.05$ ).

To test if atropine sulfate facilitates LTP during IMM, atropine sulfate or saline was injected 15 min before the delivery of tetanus during IMM (Fig. 3B and D). LTP induced during IMM following atropine sulfate injection was not significantly different from that following saline injection. At the stratum oriens electrode, repeated measures block two-way ANOVA did not show any significant main $\left(F_{(1,5)}=0.74, P=0.43\right)$ or interaction $\left(F_{(9,45)}=1.51, P=0.17\right)$ effect. Similarly, at the stratum radiatum electrode, there was no significant main $\left(F_{(1,5)}=3.77, P=0.11\right)$ or interaction $\left(F_{(9,45)}=0.92\right.$, $P=0.52$ ) effect.

To determine whether handling/injection affects LTP induced during SPIN, the same rats that received no injection in the first experiment (SPIN; Fig. 2A and B) were compared with when they were injected with saline in the second experiment (saline-SPIN; Fig. $3 \mathrm{~A}$ and $\mathrm{C}$ ). LTP induced during SPIN was not significantly different with or without saline injection. At the stratum oriens electrode, repeated measures block two-way ANOVA did not show any significant main $\left(F_{(1,4)}=0.01, P=0.96\right)$ or interaction $\left(F_{(9,36)}=0.80, P=0.62\right)$ effect. Likewise, at the stratum radiatum electrode, there was no significant main $\left(F_{(1,4)}=0.79, P=0.43\right)$ or interaction $\left(F_{(9,36)}=0.29, P=0.97\right)$ effect.

\subsection{Effect of lesion of septohippocampal cholinergic cells on LTP}

To investigate whether cholinergic septohippocampal neurons contribute to hippocampal LTP, cholinergic neurons were lesioned by bilateral infusion of cholinotoxin 192 IgG-SAP into the MS. Both groups of rats, control sham-lesion $(n=4)$ and 192-IgG-SAP lesion $(n=6)$ groups, showed that LTP was induced during either IMM or SPIN, at both stratum oriens and stratum radiatum electrodes. In sham-lesion rats, LTP was larger when the tetanus was delivered during SPIN than during IMM (Fig. 4A and C). At the 
A

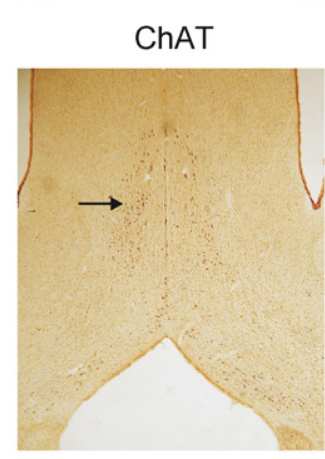

Sham

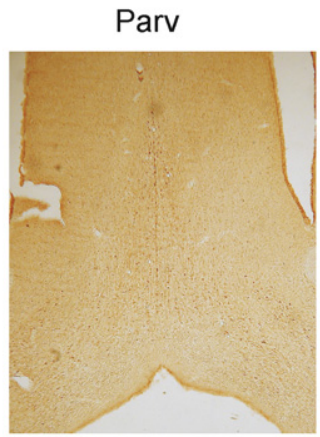

$192 \lg G-S A P$

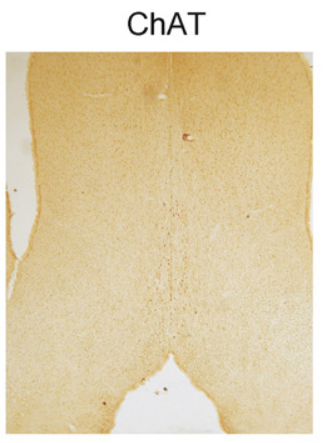

Parv

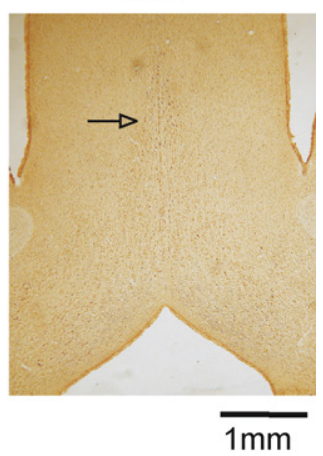

B

Sham

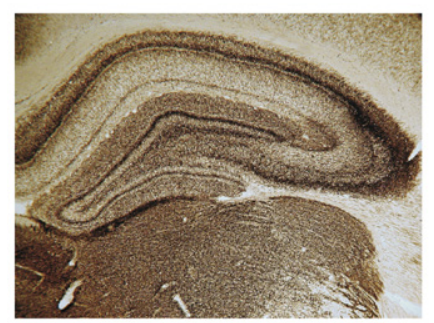

192 lgG-SAP

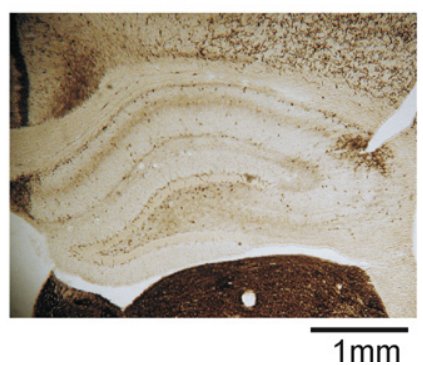

Fig. 5. Photomicrographs of representative coronal sections of the medial septum (MS) and the hippocampus in a sham-lesion and a 192 IgG-saporin (192 IgG-SAP) lesion rat. (A) Choline acetyltransferase (ChAT)- and parvalbumin (Parv) immunohistochemistry were performed on MS sections. (B) Hippocampal sections were stained for acetylcholinesterase (AChE). Note that there is a reduction of ChAT-immunopositive cholinergic neurons in the MS and a depletion of hippocampal AChE, as shown by a lighter stain, in the 192 IgG-SAP lesion rat. Parv-immunopositive GABAergic neurons in the MS were not affected. Solid and open arrows point to a ChAT- and Parv-immunopositive cell respectively.

stratum oriens electrode, repeated measures block two-way ANOVA showed significant main $\left(F_{(1,3)}=142.45, P<0.002\right)$ and interaction $\left(F_{(9,27)}=2.51, P<0.04\right)$ effects, with significant differences between SPIN and IMM revealed by Newman-Keuls post hoc tests at all times except 90 min post-tetanus. At the stratum radiatum electrode, LTP induced during SPIN as compared that induced during IMM was enhanced for the entire $180 \mathrm{~min}$ posttetanus, as demonstrated by Newman-Keuls post hoc tests after a significant interaction effect $\left(F_{(9,27)}=4.36, P<0.002\right)$ without a significant main effect $\left(F_{(1,3)}=8.14, P=0.065\right.$; repeated measures block two-way ANOVA).

In contrast, distinct from sham-lesion rats, LTP induced during SPIN was not significantly different from that during IMM in 192 IgG-SAP lesion rats (Fig. 4B and D). At the stratum oriens electrode, repeated measures block two-way ANOVA did not show any significant main $\left(F_{(1,5)}=4.13, P=0.10\right)$ or interaction $\left(F_{(9,45)}=0.74\right.$, $P=0.67$ ) effect in 192 IgG-SAP lesion rats. Likewise, at the stratum radiatum electrode, there was no significant main $\left(F_{(1,5)}=0.35\right.$, $P=0.58)$ or interaction $\left(F_{(9,45)}=0.41, P=0.92\right)$ effect in 192 IgG-SAP lesion rats.

When compared to control sham-lesion rats $(n=4)$, a decrease in the number of ChAT-immunopositive cells in the MS was found in $192 \mathrm{IgG}$-SAP lesion rats ( $n=6$; Figs. 5A and 6A). Two-way (group $\mathrm{x}$ section location) ANOVA showed a significant reduction in the number of ChAT-immunopositive neurons in 192 IgG-SAP lesion rats, as compared to sham-lesion rats $\left(F_{(1,2)}=154.64, P<0.0001\right.$; Fig. 6A). Newman-Keuls post hoc test displayed a significant decrease in the number of ChAT-immunopositive cells in 192 IgGSAP lesion as compared to sham-lesion rats in all three frontal levels $(P<0.01$, respectively). By contrast, the number of Parvimmunopositive cells in 192 IgG-SAP lesion rats was not different from that in sham-lesion rats, as confirmed by a two-way ANOVA
$\left(F_{(1,2)}=1.06, P=0.31\right.$; Figs. $5 \mathrm{~A}$ and $\left.6 \mathrm{~B}\right)$. Moreover, there was a marked loss of AChE staining in the hippocampus in $192 \mathrm{IgG}-\mathrm{SAP}$ lesion rats, as compared with sham-lesion rats (Fig. 5B).

\section{Discussion}

This present study provides original results that vestibular stimulation by passive whole-body rotation enhanced hippocampal basal-dendritic LTP in freely behaving rats. LTP was facilitated when tetanus was delivered during rotation as compared to during awake-immobility. Systemic cholinergic blockade by atropine sulfate or selective cholinotoxic (192 IgG-saporin) lesion of the MS abolished the enhancement of LTP. Therefore, LTP enhancement is mediated by activation of septohippocampal cholinergic neurons during rotation.

\subsection{Vestibular stimulation enhances LTP}

Basal dendritic LTP was enhanced when the tetanus was delivered during walking as compared to during awake-immobility [26]. This is consistent with our results in which facilitation of LTP was observed when the rat was tetanized during whole-body passive rotation compared to during awake-immobility. A recent study showed that bilateral ablation of the vestibular apparatus had no effect on hippocampal LTP in behaving rats [52]. However, the latter study did not investigate LTP induced during different behaviors such as walking and rotation. To the best of our knowledge, there have been no studies demonstrating enhancement of hippocampal LTP by vestibular stimulation. A number of studies showed that sensory stimulation alters hippocampal LTP. LTP recorded in CA1 under anesthesia was larger in rats raised in 12:12 h light/dark cycle than those raised in complete darkness since birth [53]. A recent study 
A

ChAT

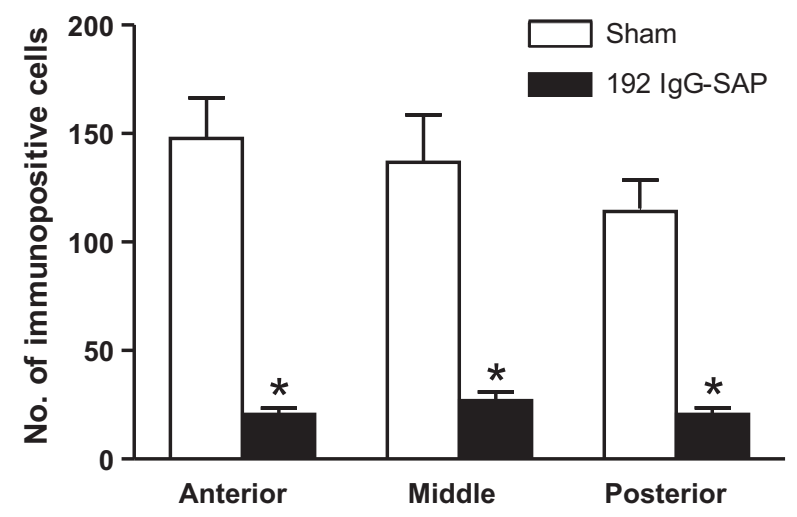

B

Parv

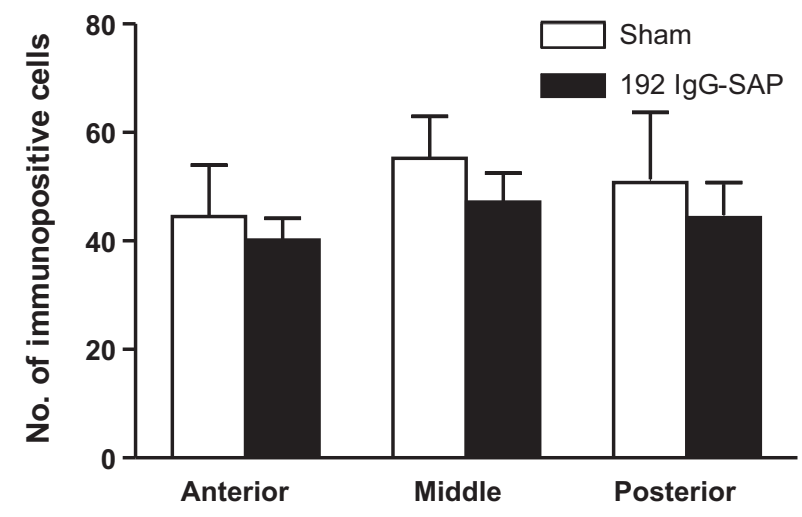

Fig. 6. Counts of choline acetyltransferase (ChAT)- and parvalbumin (Parv)immunopositive cells from coronal sections of the medial septum (MS) of 192 IgG-saporin (192 IgG-SAP) lesion rats $(n=6)$ and sham-lesion rats $(n=4)$. (A) A significant decrease in the number of ChAT-immunopositive cholinergic neurons in 192 IgG-SAP as compared to sham lesion rats was observed in MS sections at three different anterior-posterior levels. (B) The number of Parv-immunopositive GABAergic neurons was not significantly different between sham and 192 IgG-SAP lesion rats. Values are expressed as mean \pm SEM. ${ }^{*} P<0.01$ : difference between 192 IgG-SAP lesion and sham-lesion rats at a particular level, using Newman-Keuls test after a significant two-way ANOVA.

demonstrated that LTP when recorded in the dentate gyrus during the dark phase was larger than that during the light phase in behaving rats [54].

Previous studies suggested that vestibular and other sensory information are transmitted to and processed in the hippocampus to facilitate spatial navigation [55-57]. Vestibular inputs are necessary for path integration [58-61]. Passive rotation has been shown to modulate the activity of place cells $[62,63]$ while bilateral vestibular inactivation or damage abolished location-specific firing of place cells $[64,65]$. We suggest here that vestibular stimulation enhanced hippocampal LTP, which may be necessary for the formation of place fields [66-68]. Degradation of hippocampal place fields during walking by cholinergic blockade [69] suggests that acetylcholine in the hippocampus is involved in place field formation, perhaps by enhancing LTP.

Besides depolarization by blocking potassium conductances [70,71] and disinhibition by suppressing GABA release [72], acetylcholine in the hippocampus may potentiate basal-dendritic LTP by facilitating NMDA receptors and their signaling pathways [73,74]. LTP in hippocampal CA1 is sensitive to NMDA receptor antagonists including open-channel blocker MK-801 [75,76]. Moreover,
NMDA receptor antagonists, including MK-801, dose-dependently suppressed LTP induction in the dentate gyrus and impaired air righting, a set of complex movements requiring an intact vestibular labyrinth [77].

We showed that LTP was larger when induced in the presence of a rotation-induced hippocampal theta rhythm than when induced during immobility when theta was absent. A theta rhythm was observed during passive rotation [33] and walking while large irregular activity was observed during immobility $[28,78]$. Walking [27] and caloric vestibular stimulation [34,35] were shown to increase acetylcholine level in the hippocampus, and a high acetylcholine level was associated with the presence of a theta rhythm $[28,36,37,78,79]$. We showed here that cholinergic activation during a rotation-induced theta rhythm is required for the enhancement of LTP. GABAergic and glutamatergic neurons in the MS may participate in generating a theta rhythm [32,80-82], but the participation of these non-cholinergic inputs in hippocampal LTP during rotation and walking has not been shown.

\subsection{Septohippocampal cholinergic modulation of LTP}

Several in vitro studies have demonstrated a cholinergic enhancement of hippocampal LTP using cholinergic agonists or AChE inhibitors $[21,23,83]$. In anesthetized rats, hippocampal LTP facilitated by tetanic stimulation of the MS was blocked by systemic administration of cholinergic antagonists [24,25] and MS tetanus delivered longer than $5 \mathrm{~min}$ before hippocampal LTP induction will not potentiate hippocampal responses [25]. On the other hand, tetanic stimulation of the MS has been shown to suppress hippocampal LTP in anesthetized rats [84], but MS tetanus was delivered $10 \mathrm{~min}$ before hippocampal LTP induction and the tetanus by itself induced no change in CA1 population spike. The duration of LTP in the dentate gyrus was prolonged after treatment with AChE inhibitors in aged behaving rats [85]. An AChE inhibitor physostigmine also facilitated basal dendritic LTP in CA1 of behaving rats during awake-immobility [86].

We demonstrated that atropine sulfate and selective lesion of septohippocampal cholinergic neurons blocked the enhancement of LTP induced during rotation. Septal infusion of cholinotoxin 192 IgG-saporin effectively eliminated $\sim 80 \%$ of cholinergic ChAT-immunopositive cells, without affecting GABAergic Parvimmunopositive cells. Since the MS is the main source of acetylcholine for the hippocampus [4,5,87], cholinergic influence on hippocampal LTP is expected to decrease drastically after 192 IgG-saporin lesion of the MS. The present results are consistent with previous studies in finding that pretreatment with cholinergic receptor antagonist scopolamine or specific M1 receptor antagonist pirenzepine or with septal 192-IgG-saporin lesion abolished the facilitation of LTP by walking as compared to immobility $[26,86]$. These results led us to propose that vestibular stimulation activates septohippocampal cholinergic neurons that release acetylcholine in the hippocampus, modulating hippocampal synaptic transmission and plasticity.

\section{Conclusion}

This present study provides original results that vestibular stimulation by passive whole-body rotation activates a septohippocampal cholinergic input, leading to enhancement of basal dendritic LTP in hippocampal CA1 of behaving rats. Besides participating in formation of spatial memory $[3,88,89]$, septohippocampal cholinergic neurons may also be important for sensorimotor processing in which activation of the vestibular system provides a sensory signal to assist in motor planning [90]. A number of studies have demonstrated that vestibular stimulation can improve cognition in humans (reviewed in [91-93]). Given that synaptic plasticity 
is altered in patients with Alzheimer's disease [94] and degeneration of basal forebrain cholinergic neurons is a pathological hallmark of this disease $[14,15,95,96]$, vestibular stimulation may provide a novel treatment to improve hippocampus-dependent cognitive deficits in affected patients.

\section{Acknowledgements}

This study was financially supported by operating grants from Canadian Institutes of Health Research (15685) and Natural Sciences and Engineering Research Council, and a Canadian Commonwealth Scholarship to S.K. Tai.

\section{References}

[1] Jerusalinsky D, Kornisiuk E, Izquierdo I. Cholinergic neurotransmission and synaptic plasticity concerning memory processing. Neurochemical Research 1997;22:507-15.

[2] Sarter M, Hasselmo ME, Bruno JP, Givens B. Unraveling the attentional functions of cortical cholinergic inputs: interactions between signal-driven and cognitive modulation of signal detection. Brain Research Brain Research Reviews 2005;48:98-111, http://dx.doi.org/10.1016/j.brainresrev.2004.08.006.

[3] Hasselmo ME. The role of acetylcholine in learning and memory. Current Opinion in Neurobiology 2006;16:710-5, http://dx.doi.org/10.1016/ j.conb.2006.09.002.

[4] Mesulam MM, Mufson EJ, Levey AI, Wainer BH. Cholinergic innervation of cortex by the basal forebrain: cytochemistry and cortical connections of the septal area, diagonal band nuclei, nucleus basalis (substantia innominata), and hypothalamus in the rhesus monkey. Journal of Comparative Neurology 1983;214:170-97, http://dx.doi.org/10.1002/cne.902140206.

[5] Mesulam MM, Mufson EJ, Wainer BH, Levey AI. Central cholinergic pathways in the rat: an overview based on an alternative nomenclature (Ch1-Ch6). Neuroscience 1983;10:1185-201.

[6] Kesner RP. Reevaluation of the contribution of the basal forebrain cholinergic system to memory. Neurobiology of Aging 1988;9:609-16.

[7] Givens BS, Olton DS. Cholinergic and GABAergic modulation of medial septal area: effect on working memory. Behavioral Neuroscience 1990;104:849-55.

[8] Shen J, Barnes CA, Wenk GL, McNaughton BL. Differential effects of selective immunotoxic lesions of medial septal cholinergic cells on spatial working and reference memory. Behavioral Neuroscience 1996;110:1181-6.

[9] Walsh TJ, Herzog CD, Gandhi C, Stackman RW, Wiley RG. Injection of IgG 192saporin into the medial septum produces cholinergic hypofunction and dosedependent working memory deficits. Brain Research 1996;726:69-79.

[10] Chang Q Gold PE. Impaired and spared cholinergic functions in the hippocampus after lesions of the medial septum/vertical limb of the diagonal band with 192 IgG-saporin. Hippocampus 2004;14:170-9, http://dx.doi.org/10.1002/hipo.10160.

[11] Berger-Sweeney J, Heckers S, Mesulam MM, Wiley RG, Lappi DA, Sharma M. Differential effects on spatial navigation of immunotoxin-induced cholinergic lesions of the medial septal area and nucleus basalis magnocellularis. Journal of Neuroscience 1994;14:4507-19.

[12] Baxter MG, Bucci DJ, Gorman LK, Wiley RG, Gallagher M. Selective immunotoxic lesions of basal forebrain cholinergic cells: effects on learning and memory in rats. Behavioral Neuroscience 1995;109:714-22.

[13] McMahan RW, Sobel TJ, Baxter MG. Selective immunolesions of hippocampal cholinergic input fail to impair spatial working memory. Hippocampus 1997;7:130-6, doi: 2-R.

[14] Bartus RT, Dean 3rd RL, Beer B, Lippa AS. The cholinergic hypothesis of geriatric memory dysfunction. Science 1982;217:408-14

[15] Francis PT, Palmer AM, Snape M, Wilcock GK. The cholinergic hypothesis of Alzheimer's disease: a review of progress. Journal of Neurology, Neurosurgery and Psychiatry 1999;66:137-47.

[16] Martin SJ, Grimwood PD, Morris RG. Synaptic plasticity and memory: an evaluation of the hypothesis. Annual Review of Neuroscience 2000;23:649-711, http://dx.doi.org/10.1146/annurev.neuro.23.1.649.

[17] Abraham WC, Williams JM. Properties and mechanisms of LTP maintenance. Neuroscientist 2003;9:463-74, http://dx.doi.org/10.1177/ 1073858403259119 .

[18] Neves G, Cooke SF, Bliss TV. Synaptic plasticity, memory and the hippocampus: a neural network approach to causality. Nature Reviews Neuroscience 2008;9:65-75, http://dx.doi.org/10.1038/nrn2303.

[19] Bliss TV, Gardner-Medwin AR. Long-lasting potentiation of synaptic transmission in the dentate area of the unanaesthetized rabbit following stimulation of the perforant path. Journal of Physiology 1973;232:357-74.

[20] Bliss TV, Lomo T. Long-lasting potentiation of synaptic transmission in the dentate area of the anaesthetized rabbit following stimulation of the perforant path. Journal of Physiology 1973;232:331-56.

[21] Blitzer RD, Gil O, Landau EM. Cholinergic stimulation enhances long-term potentiation in the CA1 region of rat hippocampus. Neuroscience Letters 1990;119:207-10.
[22] Auerbach JM, Segal M. Muscarinic receptors mediating depression and longterm potentiation in rat hippocampus. Journal of Physiology 1996;492(Pt 2):479-93.

[23] Shimoshige Y, Maeda T, Kaneko S, Akaike A, Satoh M. Involvement of M2 receptor in an enhancement of long-term potentiation by carbachol in Schaffer collateral-CA1 synapses of hippocampal slices. Neuroscience Research 1997;27:175-80.

[24] Markevich V, Scorsa AM, Dawe GS, Stephenson JD. Cholinergic facilitation and inhibition of long-term potentiation of CA1 in the urethane-anaesthetized rats. Brain Research 1997;754:95-102.

[25] Ovsepian SV, Anwyl R, Rowan MJ. Endogenous acetylcholine lowers the threshold for long-term potentiation induction in the CA1 area through muscarinic receptor activation: in vivo study. European Journal of Neuroscience 2004;20:1267-75, http://dx.doi.org/10.1111/j.1460-9568.2004.03582.x.

[26] Leung LS, Shen B, Rajakumar N, Ma J. Cholinergic activity enhances hippocampal long-term potentiation in CA1 during walking in rats. Journal of Neuroscience 2003;23:9297-304

[27] Dudar JD, Whishaw IQ Szerb JC. Release of acetylcholine from the hippocampus of freely moving rats during sensory stimulation and running. Neuropharmacology 1979;18:673-8.

[28] Vanderwolf $\mathrm{CH}$. Neocortical and hippocampal activation relation to behavior: effects of atropine, eserine, phenothiazines, and amphetamine. Journal of Comparative and Physiological Psychology 1975;88:300-23.

[29] Leung LW. Spectral analysis of hippocampal EEG in the freely moving rat: effects of centrally active drugs and relations to evoked potentials. Electroencephalography and Clinical Neurophysiology 1985;60:65-77.

[30] Lee MG, Chrobak JJ, Sik A, Wiley RG, Buzsaki G. Hippocampal theta activity following selective lesion of the septal cholinergic system. Neuroscience 1994;62:1033-47.

[31] Bassant MH, Apartis E, Jazat-Poindessous FR, Wiley RG, Lamour YA. Selective immunolesion of the basal forebrain cholinergic neurons: effects on hippocampal activity during sleep and wakefulness in the rat. Neurodegeneration 1995;4:61-70.

[32] Yoder RM, Pang KC. Involvement of GABAergic and cholinergic medial septal neurons in hippocampal theta rhythm. Hippocampus 2005;15:381-92, http://dx.doi.org/10.1002/hipo.20062.

[33] Tai SK, Ma J, Ossenkopp KP, Leung LS. Activation of immobilityrelated hippocampal theta by cholinergic septohippocampal neurons during vestibular stimulation. Hippocampus 2012;22:914-25, http://dx.doi.org/10.1002/hipo.20955.

[34] Horii A, Takeda N, Mochizuki T, Okakura-Mochizuki K, Yamamoto Y, Yamatodani A. Effects of vestibular stimulation on acetylcholine release from rat hippocampus: an in vivo microdialysis study. Journal of Neurophysiology 1994;72:605-11.

[35] Horii A, Takeda N, Mochizuki T, Okakura-Mochizuki K, Yamamoto Y, Yamatodani A, Kubo T. Vestibular modulation of the septo-hippocampal cholinergic system of rats. Acta Oto-laryngologica Supplement 1995;520(Pt 2):395-8.

[36] Keita MS, Frankel-Kohn L, Bertrand N, Lecanu L, Monmaur P. Acetylcholine release in the hippocampus of the urethane anaesthetised rat positively correlates with both peak theta frequency and relative power in the theta band. Brain Research 2000;887:323-34.

[37] Zhang H, Lin SC, Nicolelis MA. Spatiotemporal coupling between hippocampal acetylcholine release and theta oscillations in vivo. Journal of Neuroscience 2010;30:13431-40, http://dx.doi.org/10.1523/JNEUROSCI. 1144-10.2010.

[38] Luo T, Leung LS. Endogenous histamine facilitates long-term potentiation in the hippocampus during walking. Journal of Neuroscience 2010;30:7845-52, http://dx.doi.org/10.1523/JNEUROSCI. 1127-10.2010.

[39] Paxinos G, Watson C. The Rat Brain in Stereotaxic Coordinates. Compact 3rd ed. San Diego: Academic Press; 1997.

[40] Wiley RG, Oeltmann TN, Lappi DA. Immunolesioning: selective destruction of neurons using immunotoxin to rat NGF receptor. Brain Research 1991;562:149-53, 0006-8993(91)91199-B [pii].

[41] Ma J, Shen B, Rajakumar N, Leung LS. The medial septum mediates impairment of prepulse inhibition of acoustic startle induced by a hippocampal seizure or phencyclidine. Behavioural Brain Research 2004;155:153-66, http://dx.doi.org/10.1016/j.bbr.2004.04.010

[42] Leung LS, Shen B. Long-term potentiation in hippocampal CA1: effects of afterdischarges, NMDA antagonists, and anticonvulsants. Experimental Neurology 1993;119:205-14, http://dx.doi.org/10.1006/exnr.1993.1022.

[43] Leung LS, Shen B. Long-term potentiation at the apical and basal dendritic synapses of CA1 after local stimulation in behaving rats. Journal of Neurophysiology 1995; 73:1938-46.

[44] Dale HH. The action of certain esters and ethers of choline, and their relation to muscarine. Journal of Pharmacology and Experimental Therapeutics 1914;6:147-90

[45] Richards MH. Pharmacology and second messenger interactions of cloned muscarinic receptors. Biochemical Pharmacology 1991;42:1645-53.

[46] Zwart R, Vijverberg HP. Potentiation and inhibition of neuronal nicotinic receptors by atropine: competitive and noncompetitive effects. Molecular Pharmacology 1997;52:886-95.

[47] Parker JC, Sarkar D, Quick MW, Lester RA. Interactions of atropine with heterologously expressed and native alpha 3 subunit-containing nicotinic acetylcholine receptors. British Journal of Pharmacology 2003:138:801-10, http://dx.doi.org/10.1038/sj.bjp.0705124. 
[48] Koelle GB, Friedenwald JS. A histochemical method for localizing cholinesterase activity. Proceedings of the Society for Experimental Biology and Medicine 1949;70:617-22.

[49] Leung LS, Peloquin P. Cholinergic modulation differs between basal and apical dendritic excitation of hippocampal CA1 pyramidal cells. Cerebral Cortex 2010;20:1865-77, http://dx.doi.org/10.1093/cercor/bhp251.

[50] Shin J, Kim D, Bianchi R, Wong RK, Shin HS. Genetic dissection of theta rhythm heterogeneity in mice. Proceedings of the National Academy of Sciences of the United States of America 2005;102:18165-70, http://dx.doi.org/10.1073/pnas.0505498102, 0505498102 [pii].

[51] Shin J. Passive rotation-induced theta rhythm and orientation homeostasis response. Synapse 2010;64:409-15, http://dx.doi.org/10.1002/syn.20742.

[52] Zheng Y, Mason-Parker SE, Logan B, Darlington CL, Smith PF, Abraham WC. Hippocampal synaptic transmission and LTP in vivo are intact following bilateral vestibular differentiation in the rat. Hippocampus 2010;20:461-8, http://dx.doi.org/10.1002/hipo.20645.

[53] Talaei SA, Sheibani V, Salami M. Light deprivation improves melatonin related suppression of hippocampal plasticity. Hippocampus 2010;20:447-55, http://dx.doi.org/10.1002/hipo.20650.

[54] Bowden JB, Abraham WC, Harris KM. Differential effects of strain, circadian cycle, and stimulation pattern on LTP and concurrent LTD in the dentate gyrus of freely moving rats. Hippocampus 2011, http://dx.doi.org/10.1002/hipo.20972.

[55] Berthoz A. How does the cerebral cortex process and utilize vestibular signals? In: Baloh R, Halmagyi G, editors. Disorders of the vestibular system. Oxford: Oxford University Press; 1996. p. 113-25.

[56] Etienne AS, Jeffery KJ. Path integration in mammals. Hippocampus 2004;14:180-92, http://dx.doi.org/10.1002/hipo.10173.

[57] Tsanov M, Manahan-Vaughan D. Synaptic plasticity from visual cortex to hippocampus: systems integration in spatial information processing. Neuroscientist 2008;14:584-97, http://dx.doi.org/10.1177/1073858408315655.

[58] O'Keefe J, Nadel L. The hippocampus as a cognitive map. Oxford: Clarendon Press; 1978,570 pp.

[59] Mittelstaedt ML, Mittelstaedt H. Homing by path integration in a mammal. Naturewissenschaften 1980;67:556-67.

[60] McNaughton BL, Barnes CA, Gerrard JL, Gothard K, Jung MW, Knierim JJ, Kudrimoti H, Qin Y, Skaggs WE, Suster M, Weaver KL. Deciphering the hippocampal polyglot: the hippocampus as a path integration system. Journal of Experimental Biology 1996;199:173-85.

[61] McNaughton BL, Battaglia FP, Jensen O, Moser EI, Moser MB. Path integration and the neural basis of the 'cognitive map'. Nature Reviews Neuroscience 2006;7:663-78, http://dx.doi.org/10.1038/nrn1932.

[62] Knierim JJ, Kudrimoti HS, McNaughton BL. Place cells, head direction cells, and the learning of landmark stability. Journal of Neuroscience 1995:15:1648-59.

[63] Wiener SI, Korshunov VA, Garcia R, Berthoz A. Inertial, substratal and landmark cue control of hippocampal CA1 place cell activity. European Journal of Neuroscience 1995;7:2206-19.

[64] Stackman RW, Clark AS, Taube JS. Hippocampal spatial representations require vestibular input. Hippocampus 2002;12:291-303, http://dx.doi.org/10.1002/hipo.1112.

[65] Russell NA, Horii A, Smith PF, Darlington CL, Bilkey DK. Long-term effects of permanent vestibular lesions on hippocampal spatial firing. Journal of Neuroscience 2003;23:6490-8.

[66] Muller RU, Stead M, Pach J. The hippocampus as a cognitive graph. Journal of General Physiology 1996;107:663-94.

[67] Dragoi G, Harris KD, Buzsaki G. Place representation within hippocampal networks is modified by long-term potentiation. Neuron 2003;39: 843-53.

[68] Isaac JT, Buchanan KA, Muller RU, Mellor JR. Hippocampal place cell firing patterns can induce long-term synaptic plasticity in vitro. Journal of Neuroscience 2009;29:6840-50, http://dx.doi.org/10.1523/JNEUROSCI. 0731-09.2009.

[69] Brazhnik ES, Muller RU, Fox SE. Muscarinic blockade slows and degrades the location-specific firing of hippocampal pyramidal cells. Journal of Neuroscience 2003;23:611-21.

[70] Krnjevic K. Central cholinergic mechanisms and function. Progress in Brain Research 1993;98:285-92.

[71] Madison DV, Lancaster B, Nicoll RA. Voltage clamp analysis of cholinergic action in the hippocampus. Journal of Neuroscience 1987;7:733-41.

[72] Krnjevic K, Ropert N, Casullo J. Septohippocampal disinhibition. Brain Research 1988;438:182-92.

[73] Markram H, Segal M. The inositol 1,4,5-trisphosphate pathway mediates cholinergic potentiation of rat hippocampal neuronal responses to NMDA. Journal of Physiology 1992;447:513-33.
[74] Marino MJ, Rouse ST, Levey AI, Potter LT, Conn PJ. Activation of the genetically defined $\mathrm{m} 1$ muscarinic receptor potentiates N-methyl-D-aspartate (NMDA) receptor currents in hippocampal pyramidal cells. Proceedings of the National Academy of Sciences of the United States of America 1998;95:11465-70.

[75] Abraham WC, Mason SE. Effects of the NMDA receptor/channel antagonists CPP and MK801 on hippocampal field potentials and long-term potentiation in anesthetized rats. Brain Research 1988;462:40-6.

[76] Leung LS, Shen B. N-methyl-D-aspartate receptor antagonists are less effective in blocking long-term potentiation at apical than basal dendrites in hippocampal CA1 of awake rats. Hippocampus 1999;9:617-30.

[77] Wayner MJ, Tracy HA, Armstrong DL, Phelix CF. Air righting: role of the NMDA receptor channel and hippocampal LTP. Physiology and Behavior 2000;69:505-10.

[78] Leung LS. Generation of theta and gamma rhythms in the hippocampus. Neuroscience and Biobehavioral Reviews 1998;22:275-90.

[79] Leung LS, Vanderwolf $\mathrm{CH}$. Behavior-dependent evoked potentials in the hippocampal CA1 region of the rat. II. Effect of eserine, atropine, ether and pentobarbital. Brain Research 1980;198:119-33.

[80] Brazhnik ES, Fox SE. Action potentials and relations to the theta rhythm of medial septal neurons in vivo. Experimental Brain Research 1999;127:244-58.

[81] Alreja M, Wu M, Liu W, Atkins JB, Leranth C, Shanabrough M. Muscarinic tone sustains impulse flow in the septohippocampal GABA but not cholinergic pathway: implications for learning and memory. Journal of Neuroscience 2000;20:8103-10.

[82] Huh CY, Goutagny R, Williams S. Glutamatergic neurons of the mouse medial septum and diagonal band of Broca synaptically drive hippocampal pyramidal cells: relevance for hippocampal theta rhythm. Journal of Neuroscience 2010;30:15951-61, http://dx.doi.org/10.1523/JNEUROSCI. 3663-10.2010.

[83] Hirotsu I, Hori N, Katsuda N, Ishihara T. Effect of anticholinergic drug on longterm potentiation in rat hippocampal slices. Brain Research 1989;482:194-7.

[84] Newlon PG, Goldberg SJ, Hayes RL. High-frequency septal stimulation suppresses long-term potentiation (LTP) in the CA1 region of rat hippocampus. Brain Research 1991;544:320-4.

[85] Barnes CA, Rao G, Houston FP. LTP induction threshold change in old rats at the perforant path-granule cell synapse. Neurobiology of Aging 2000;21:613-20.

[86] Doralp S, Leung LS. Cholinergic modulation of hippocampal CA1 basaldendritic long-term potentiation. Neurobiology of Learning and Memory 2008;90:382-8, http://dx.doi.org/10.1016/j.nlm.2008.05.013.

[87] Bagnoli P, Beaudet A, Stella M, Cuenod M. Selective retrograde labeling of cholinergic neurons with [3H]choline. Journal of Neuroscience 1981;1:691-5.

[88] Givens B, Olton DS. Bidirectional modulation of scopolamine-induced working memory impairments by muscarinic activation of the medial septal area. Neurobiology of Learning and Memory 1995;63:269-76, http://dx.doi.org/10.1006/nlme.1995.1031.

[89] Roland JJ, Mark K, Vetreno RP, Savage LM. Increasing hippocampal acetylcholine levels enhance behavioral performance in an animal model of diencephalic amnesia. Brain Research 2008;1234:116-27, http://dx.doi.org/10.1016/j.brainres.2008.07.090.

[90] Bland BH, Oddie SD. Theta band oscillation and synchrony in the hippocampal formation and associated structures: the case for its role in sensorimotor integration. Behavioural Brain Research 2001;127:119-36.

[91] Smith PF, Darlington CL, Zheng Y. Move it or lose it - is stimulation of the vestibular system necessary for normal spatial memory? Hippocampus 2010;20:36-43, http://dx.doi.org/10.1002/hipo.20588.

[92] Smith PF, Geddes LH, BaekJH, Darlington CL, Zheng Y. Modulation of memory by vestibular lesions and galvanic vestibular stimulation. Frontiers in Neurology 2010;1:141, http://dx.doi.org/10.3389/fneur.2010.00141.

[93] Utz KS, Dimova V, Oppenlander K, Kerkhoff G. Electrified minds: transcranial direct current stimulation (tDCS) and galvanic vestibular stimulation (GVS) as methods of non-invasive brain stimulation in neuropsychology - a review of current data and future implications. Neuropsychologia 2010;48:2789-810, http://dx.doi.org/10.1016/j.neuropsychologia.2010.06.002.

[94] Gong Y, Lippa CF. Review: disruption of the postsynaptic density in Alzheimer's disease and other neurodegenerative dementias. American Journal of Alzheimer's Disease and Other Dementias 2010;25:547-55, http://dx.doi.org/10.1177/1533317510382893.

[95] Wu CK, Thal L, Pizzo D, Hansen L, Masliah E, Geula C. Apoptotic signals within the basal forebrain cholinergic neurons in Alzheimer's disease. Experimental Neurology 2005;195:484-96, http://dx.doi.org/10.1016/ j.expneurol.2005.06.020.

[96] Wenk GL. Neuropathologic changes in Alzheimer's disease: potential targets for treatment. Journal of Clinical Psychiatry 2006;67(Suppl 3):3-7, quiz 23. 